\title{
ERKs and JNKs Mediate Hydrogen Peroxide-Induced Egr-1 Expression and Nuclear Accumulation in H9c2 Cells
}

\author{
I.-K. S. AGGELI ${ }^{1}$, I. BEIS ${ }^{1}$, C. GAITANAKI ${ }^{1}$ \\ ${ }^{1}$ Department of Animal and Human Physiology, School of Biology, Faculty of Sciences, University \\ of Athens, Athens, Greece
}

Received April 9, 2009

Accepted June 10, 2009

On-line August 12, 2009

\begin{abstract}
Summary
One of the most significant insults that jeopardize cardiomyocyte homeostasis is a surge of reactive oxygen species (ROS) in the failing myocardium. Early growth response factor-1 (Egr-1) has been found to act as a transcriptional regulator in multiple biological processes known to exert deleterious effects on cardiomyocytes. We thus investigated the signaling pathways involved in its regulation by $\mathrm{H}_{2} \mathrm{O}_{2}$. Egr- 1 mRNA levels were found to be maximally induced after $2 \mathrm{~h}$ in $\mathrm{H}_{2} \mathrm{O}_{2}$-treated $\mathrm{H} 9 \mathrm{c} 2$ cells. Egr-1 respective response at the protein level, was found to be

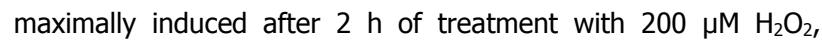
remaining elevated for $6 \mathrm{~h}$, and declining thereafter. $\mathrm{H}_{2} \mathrm{O}_{2}$ induced upregulation of Egr-1 mRNA and protein levels was ablated in the presence of agents inhibiting ERKs pathway (PD98059) and JNKs (SP600125, AS601245). Immunofluorescent experiments revealed $\mathrm{H}_{2} \mathrm{O}_{2}$-induced Egr-1 nuclear sequestration to be also ERK- and JNK-dependent. Overall, our results show for the first time the fundamental role of ERKs and JNKs in regulating Egr-1 response to $\mathrm{H}_{2} \mathrm{O}_{2}$ treatment in cardiac cells at multiple levels: mRNA, protein and subcellular distribution. Nevertheless, further studies are required to elucidate the specific physiological role of Egr-1 regarding the modulation of gene expression and determination of cell fate.
\end{abstract}

\section{Key words}

Early growth response factor-1 (Egr-1) - ERKs - JNKs $-\mathrm{H}_{2} \mathrm{O}_{2}$ • Signaling

\section{Corresponding author}

C. Gaitanaki, Dept. of Animal and Human Physiology, School of Biology, Faculty of Sciences, University of Athens, Panepistimioupolis Ilissia, 15784 Athens, Greece. Fax: +30 210 7274635. E-mail: cgaitan@biol.uoa.gr

\section{Introduction}

Oxidative stress mediated by excessive reactive oxygen species (ROS) has been shown to compromise heart function, having deleterious effects on cardiac myocytes (Byrne et al. 2003, Ferrari et al. 2004). Indeed, apoptotic mechanisms have been found to be triggered in a variety of cardiovascular pathologies including atherosclerosis, ischemic episodes, myocardial infarction as well as ischemia/reperfusion injury (Balla et al. 1991, Feuerstein and Young 2000, Flotats and Carrio 2003). Ample data from gene expression profiling experiments have led to the identification of a genetic survival program activated in numerous ROS-related cardiac disorders. The early growth response factor-1 (Egr-1) is included among the antiapoptotic genes mediating cell preservation under these adverse conditions (Depre et al. 2001).

The transcription factor Egr-1 (also termed NGF1-A, Zif/268, Krox-24) was originally identified as an immediate early response gene (Milbrandt 1987) bearing both growth inhibitory (Huang et al. 1997, Levin et al. 1995) or growth promoting properties (Eid et al. 1998). It contains a DNA binding domain that consists of three zinc fingers (Lemaire et al. 1988, Lim et al. 1987) and binds to a GC-rich sequence in the promoter of its target genes (Cao et al. 1993). Egr-1 is rapidly induced by differentiation signals (Sukhatme et al. 1988) as well as by heat shock, UV light (Lim et al. 1987) and ionizing radiation (Datta et al. 1992). In terms of its tissue distribution, Egr-1 expression is highest in brain and heart (Lanoix et al. 1998).

In particular, Egr-1 has been found to mediate 
transcriptional regulation of a variety of inflammatory and coagulant genes involved in atherosclerotic pathogenesis following vascular injury, i.e. transforming growth factor- $\beta$, intercellular adhesion molecule-1 (ICAM-1), plasminogen activator inhibitor-1 as well as platelet-derived growth factor A and B (PDGF-A and B) (Khachigian et al. 1996, Yan et al. 2000). Egr-1 is also expressed in atherosclerotic plaques (McCaffrey et al. 2000) and mechanically injured carotid arteries (Santiago et al. 1999). Eliciting salutary changes and mediating cardiac remodeling by altering the expression of genes such as atrial natriuretic factor (ANF) and $\alpha$ - or $\beta$-myosin heavy chain ( $\alpha$ - or $\beta$-MHC), Egr-1 has also been shown to promote preservation of the heart contractile machinery (Bruneau et al. 1996, Saadane et al. 1999). In addition, Fahmy and Khachigian (2002) have observed that reduction of Egr-1 levels resulted in suppression of smooth muscle cell proliferation limiting intimal hyperplasia in balloon-injured carotid.

Numerous reports confirm that among the signal transduction pathways involved in Egr-1 regulation, MAPK subfamilies are included, with compelling evidence reporting the particularly crucial role of extracellular signal-regulated kinases (ERKs) especially in cardiomyocytes (Chiu et al. 1999, deHager et al. 2001, Hodge et al. 1998). MAPKs constitute a highly conserved family of serine/threonine protein kinases which are activated via dual phosphorylation of a specific threonine and tyrosine residue (Goedert et al. 1997). The three beststudied MAPKs subfamilies include: ERKs, cJun-Nterminal kinases (JNKs) and p38-MAPK (Goedert et al. 1997, Kyriakis and Avruch 1996). Upon activation, MAPKs can be found in both the cytoplasm and nucleus, where they interact with their substrates, i.e. other protein kinases, cytoskeletal proteins as well as transcription factors (Bogoyevitch 2000, Kyriakis and Avruch 1996).

Given the emerging importance of Egr-1 function in the myocardium under oxidative stress conditions (Ross 1998), as well as the fact that the mechanism regulating its expression remains elusive, this study was undertaken in an effort to decipher the redox signal transduction pathways involved in $\mathrm{H}_{2} \mathrm{O}_{2}$-induced Egr-1 response of cardiac myocytes. Thus, we used H9c2 cardiomyoblasts as our experimental setting. This clonal cell line derived from embryonic heart ventricle retains properties of signaling pathways of adult cardiomyocytes (Kimes and Brandt 1976) which accounts for its extensive use in studies investigating signal transduction mechanisms in cardiomyocytes (Han et al. 2004, Su et al.
1999, Tanaka et al. 2003, Turner et al. 1998). In the present study, we demonstrate for the first time, the involvement of both ERK and JNK signaling pathways in Egr-1 mRNA and protein levels upregulation along with its nuclear sequestration in $\mathrm{H}_{2} \mathrm{O}_{2}$-treated cardiac cells.

\section{Methods}

\section{Materials}

Hydrogen peroxide was purchased from Merck (Darmstadt, Germany). DMSO, leupeptin, trans-epoxysuccinyl-L-leucylamido-(4-guanidino) butane (E-64), dithiothreitol (DTT) and phenylmethylsulphonyl fluoride (PMSF) were obtained from Sigma-Aldrich (St Louis, Missouri, USA). SP600125, AS601245 and PD98059 were purchased from Calbiochem-Novabiochem (La Jolla, CA, USA) while SB203580 was from Alexis Biochemicals (Lausen, Switzerland). Nitrocellulose $(0.45 \mu \mathrm{m})$ was obtained from Schleicher \& Schuell (Keene NH, USA). Prestained molecular mass markers were from New England Biolabs (Beverly, MA, USA). Secondary antibodies were from DakoCytomation (Glostrup, Denmark). Primers for the detection of Egr-1 and GAPDH were synthesized by Invitrogen Life Technologies (California, USA). Super RX film was purchased from Fuji photo film GmbH (Dusseldorf, Germany). General laboratory reagents were purchased from Sigma-Aldrich or Merck.

\section{Cell cultures, treatments and reagents}

H9c2 cells (passage 18-25; American Type Culture Collection, Rockville, MD, USA) were cultured in DMEM (PAA Laboratories GmbH, Pasching, Austria) supplemented with $10 \%(\mathrm{v} / \mathrm{v})$ heat inactivated fetal bovine serum (PAA Laboratories $\mathrm{GmbH}$ ) and antibiotics, under an atmosphere of $95 \%$ air / $5 \% \mathrm{CO}_{2}$ at $37^{\circ} \mathrm{C}$. The experiments were carried out using mononucleated myoblasts after serum had been withdrawn for $24 \mathrm{~h}$. Hydrogen peroxide $(200 \mu \mathrm{M})$ was added to the medium for the times indicated. This concentration of hydrogen peroxide is used routinely for gene expression studies in cardiomyocyte experimental settings exposed to oxidative stress (Kemp et al. 2003). When pharmacological inhibitors were used, they were dissolved in DMSO and added to the medium $30 \mathrm{~min}$ prior to treatment with $200 \mu \mathrm{M} \mathrm{H}_{2} \mathrm{O}_{2}$ as follows: PD98059 $(25 \mu \mathrm{M}), \mathrm{SP} 600125$ $(10 \mu \mathrm{M}), \operatorname{AS} 601245(1 \mu \mathrm{M}), \operatorname{SB} 203580(10 \mu \mathrm{M})$, cycloheximide $(20 \mu \mathrm{M})$ and actinomycin $\mathrm{D}(5 \mu \mathrm{g} / \mathrm{ml})$. Cells were left untreated (control) or incubated with 
either DMSO or the inhibitors alone or with the inhibitors followed by exposure to $200 \mu \mathrm{M} \mathrm{H}_{2} \mathrm{O}_{2}$ for $1 \mathrm{~h}$ (mRNA studies) or $2 \mathrm{~h}$ (protein studies), respectively. Control experiments with DMSO alone were performed for the respective duration $(1.5 \mathrm{~h}$ for Egr-1 mRNA studies and $2.5 \mathrm{~h}$ for Egr-1 protein studies).

\section{Preparation of nuclear extracts}

Nuclear extracts were prepared as previously described (Aggeli et al. 2006). Cells were harvested into buffer A (10 mM Tris- $\mathrm{HCl} \mathrm{pH}$ 7.9, $10 \mathrm{mM} \mathrm{KCl}, 1.5 \mathrm{mM}$ $\mathrm{MgCl}_{2}, 0.3 \mathrm{mM} \mathrm{Na}_{3} \mathrm{VO}_{4}, 200 \mu \mathrm{M}$ leupeptin, $10 \mu \mathrm{M} \mathrm{E}-64$, $5 \mathrm{mM}$ DTT, $300 \mu \mathrm{M}$ PMSF). Samples were centrifuged $\left(10,000 \mathrm{~g}, 5 \mathrm{~min}, 4^{\circ} \mathrm{C}\right)$ in a BR4i Jouan centrifuge, and the supernatants discarded. Pellets were re-suspended in buffer A containing $0.1 \%(\mathrm{v} / \mathrm{v})$ Nonidet P40 (10 min, $\left.4{ }^{\circ} \mathrm{C}\right)$. After centrifugation $\left(10,000 \mathrm{~g}, 5 \mathrm{~min}, 4^{\circ} \mathrm{C}\right)$, pellets were re-suspended in buffer $\mathrm{C}[20 \mathrm{mM}$ Hepes $\mathrm{pH} 7.9$, $420 \mathrm{mM} \mathrm{NaCl}, 1.5 \mathrm{mM} \mathrm{MgCl}_{2}, 0.2 \mathrm{mM}$ EDTA, $25 \%$ (v/v) glycerol, $0.3 \mathrm{mM} \mathrm{Na} \mathrm{VO}_{4}, 200 \mu \mathrm{M}$ leupeptin, $10 \mu \mathrm{M}$ E-64, $5 \mathrm{mM}$ DTT, $300 \mu \mathrm{M}$ PMSF]. After centrifugation $\left(12,000 \mathrm{~g}, 5 \mathrm{~min}, 4{ }^{\circ} \mathrm{C}\right)$ supernatants (nuclear extract) were boiled with 0.33 vol. of SDSPAGE sample buffer [SB4X: $0.33 \mathrm{M}$ Tris- $\mathrm{HCl}(\mathrm{pH} 6.8)$, $10 \% \quad(\mathrm{w} / \mathrm{v})$ SDS, $13 \%(\mathrm{v} / \mathrm{v})$ glycerol, $20 \%(\mathrm{v} / \mathrm{v})$ 2-mercaptoethanol, $0.2 \% \quad(\mathrm{w} / \mathrm{v})$ bromophenol blue]. Protein concentrations were determined using the BioRad Bradford assay reagent (Bio-Rad, Hercules, California, USA).

\section{Immunoblotting}

Protein samples $(30 \mu \mathrm{g})$ from nuclear fraction extracts were separated by SDS-PAGE on $8 \%(w / v)$ polyacrylamide gels and transferred electrophoretically onto nitrocellulose membranes. Nonspecific binding sites were blocked with $5 \%(\mathrm{w} / \mathrm{v})$ nonfat milk powder in TBST [20 mM Tris-HCl pH 7.5, $137 \mathrm{mM} \mathrm{NaCl}, 0.1 \%$ (v/v) Tween 20] for $30 \mathrm{~min}$ at room temperature. Subsequently, membranes were incubated overnight with the appropriate primary antibody [1:1000 anti-Egr-1 (sc110, Santa Cruz Biotechnology, Inc. California, USA) or 1:2000 anti-actin (A2103, Sigma-Aldrich St Louis, Missouri, USA)] at $4{ }^{\circ} \mathrm{C}$. After washing in TBST $(3 \times 5$ $\mathrm{min}$ ) blots were incubated with the respective horseradish peroxidase-conjugated secondary antibody 1:5000 in TBST containing $1 \%(\mathrm{w} / \mathrm{v})$ nonfat milk powder (60 min). After washing in TBST ( $3 \times 5 \mathrm{~min}$ ), bands were detected using enhanced chemiluminescense (ECL) (Amersham Biosciences, Uppsala, Sweden) and quantified by scanning densitometry (Gel Analyzer v. 1.0).

RNA preparation, $C D N A$ synthesis and ratiometric reverse transcription PCR (RT-PCR)

The expression of endogenous Egr-1 was determined by ratiometric reverse transcription of total RNA followed by PCR analysis. Total RNA was extracted from cells using Trizol (Invitrogen Life Technologies), according to the manufacturer's instructions. For cDNA synthesis, $2 \mu \mathrm{g}$ of total RNA was denatured in the presence of 5 pmol oligo-dT primer in a reaction volume of $13.5 \mu \mathrm{l}$ at $65{ }^{\circ} \mathrm{C}$ for $5 \mathrm{~min}$. Reverse transcription was performed with M-MLV Reverse Transcriptase (Invitrogen Life Technologies), first strand buffer (Promega, Madison, USA), dithiothreitol (Promega) and deoxy-nucleotide triphosphates (dNTPs) (Promega). The first strand reaction was incubated at $37^{\circ} \mathrm{C}$ for $1 \mathrm{~h}$. Termination of the reaction was achieved by inactivation of the reverse transcriptase at $70{ }^{\circ} \mathrm{C}$ for 5 min. PCR for Egr-1 was performed using 1.5 Units Taq (Bioron GmbH, Ludwigshafen, Germany) with sense 5'-GTG CGA GTG GAG ATC GGA AT-3' and antisense 5'- GTA ACC GCA GCA TTC CAA CT-3' primers, based on the sequence of rat Egr-1 [Genbank accession no. NM012551]. These primers amplify a 205base pair PCR product. After a $5 \mathrm{~s}$ denaturation at $95^{\circ} \mathrm{C}$, PCR was carried out for 25 cycles $\left(95^{\circ} \mathrm{C}\right.$ for $30 \mathrm{~s}, 59^{\circ} \mathrm{C}$ for $30 \mathrm{~s}$ and $72{ }^{\circ} \mathrm{C}$ for $30 \mathrm{~s}$ ), and then a final extension was done at $72{ }^{\circ} \mathrm{C}$ for $4 \mathrm{~min}$. PCR $(25$ cycles) for GAPDH was performed using the following primers: sense 5'-ACC ACA GTC CAT GCC ATC AC-3' and antisense 5'-TCC ACC ACC CTG TTG CTG TA-3' [Genbank accession no. X02231]. cDNA samples derived from "control" and treated cells were always amplified simultaneously. PCR products were separated on a $2 \%$ $(\mathrm{w} / \mathrm{v})$ agarose gel supplemented with ethidium bromide $(\mathrm{EtBr})$ at a final concentration of $100 \mu \mathrm{g} / \mathrm{l}$. Band intensities were determined using an appropriate image analysis program (Gel Analyzer v. 1.0). All values were normalized for the amount of GAPDH mRNA and estimation of fragment band size (Egr-1 205 bp, GAPDH $452 \mathrm{bp}$ ) was performed by comparison with GeneRuler 100 bp DNA ladder (Fermentas Life Sciences Inc., Hanover, USA).

\section{Immunofluorescence staining}

Cells were grown on appropriate chamber slides in plating medium and were treated after serum had been 

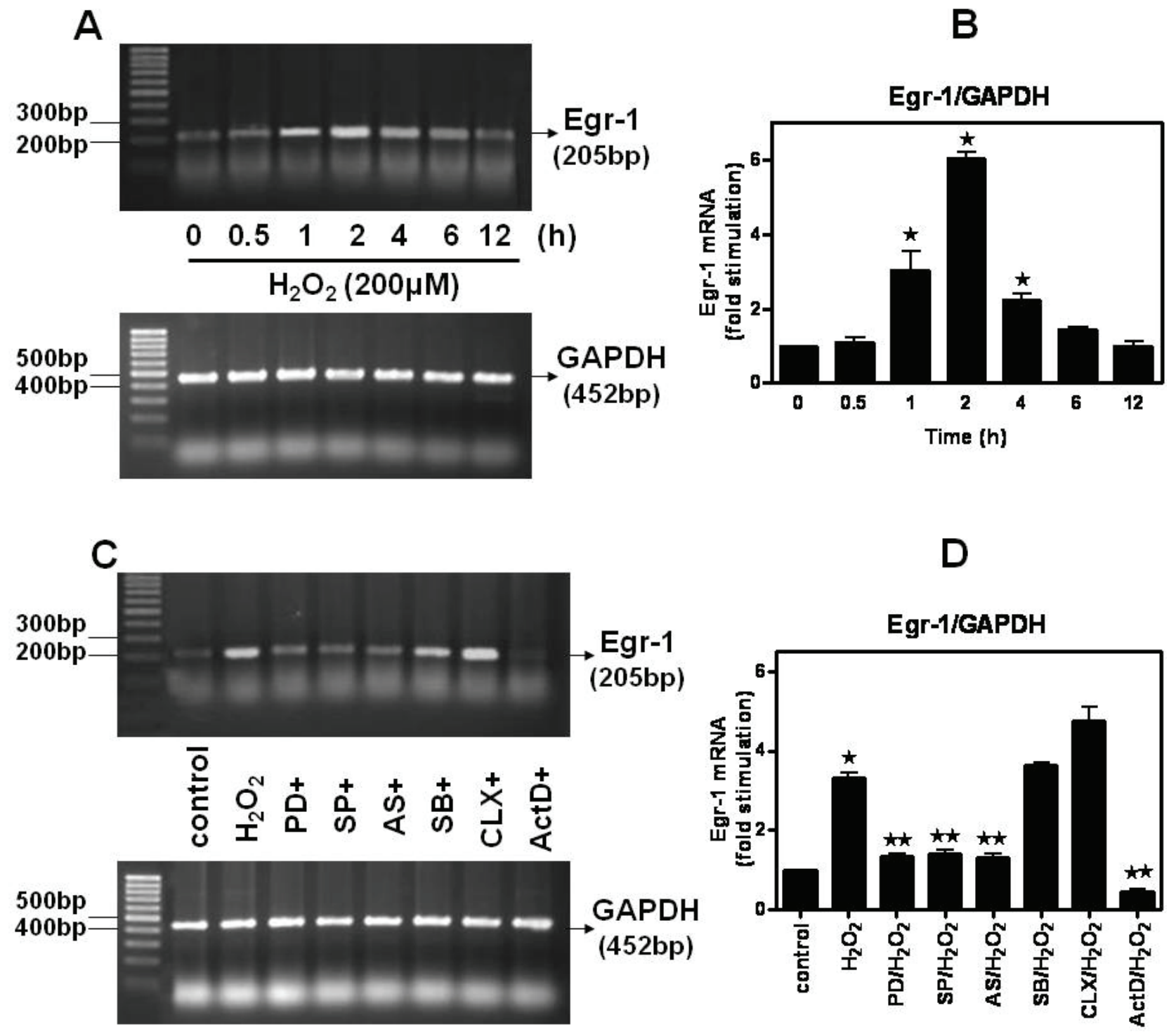

Fig. 1. Time course analysis of $\mathrm{H}_{2} \mathrm{O}_{2}$-induced Egr-1 mRNA upregulation in $\mathrm{H} 9 \mathrm{c} 2$ cardiomyoblasts; a JNK- and ERK-mediated response. (A) $\mathrm{H} 9 \mathrm{c} 2$ cells were exposed to $200 \mu \mathrm{M} \mathrm{H} \mathrm{H}_{2}$ for the times indicated. (C) $\mathrm{H} 9 \mathrm{c} 2$ cells were left untreated (control) or pre-incubated with $10 \mu \mathrm{M}$ PD98059 (PD), $10 \mu \mathrm{M}$ SP600125 (SP), $1 \mu \mathrm{M}$ AS601245 (AS), $10 \mu \mathrm{M}$ SB203580 (SB), $20 \mu \mathrm{M}$ cycloheximide (CLX), and 5 mg/ml actinomycin $D$ (ActD) for 30 min, then exposed to $200 \mu \mathrm{M} \mathrm{H}_{2} \mathrm{O}_{2}$ for $1 \mathrm{~h}$ in the absence or presence of the inhibitors. RNA was extracted and expression of Egr-1 (A and $\mathbf{C}$ upper panels) as well as GAPDH (A and $\mathbf{C}$ lower panels) mRNA was analyzed by ratiometric RT-PCR. The positions of the 500,400, 300 and 200bp markers are indicated on the left of the panels. After densitometric analysis of the PCR products, results were normalized for GAPDH and the data is presented (B and $\mathbf{D}$ ) as fold stimulation. Results are means \pm SEM for at least three independent experiments. $* \mathrm{p}<0.001$ compared to control values; $* * \mathrm{p}<0.001$ compared to identically treated cells in the absence of inhibitors.

withdrawn for $24 \mathrm{~h}$. Subsequently, cells were fixed with $4 \%(\mathrm{v} / \mathrm{v})$ formaldehyde in phosphate buffer saline (PBS) $\mathrm{pH} 7.4$ for $15 \mathrm{~min}$ at $\mathrm{R}_{\mathrm{T}}$, washed in PBS (x3) and incubated ( $5 \mathrm{~min}, \mathrm{R}_{\mathrm{T}}$ ) with $1 \%(\mathrm{w} / \mathrm{v}) \mathrm{BSA}$ in PBS containing $0.3 \%(\mathrm{v} / \mathrm{v})$ Triton X-100. Incubation with the primary antibody against Egr- $1\left(1: 100,1 \mathrm{~h}, 37^{\circ} \mathrm{C}\right)$ was followed by $0.5 \mathrm{~h}$ incubation at $37^{\circ} \mathrm{C}$ with an Alexa Fluor 488-conjugated anti-rabbit secondary antibody (1:250) (green fluorescence). After washing, cell nuclei were stained using TO-PRO-3 iodide (642/661) (1 $\mu \mathrm{M}$ in
DMSO) (red fluorescence). Following mounting, chamber slides were visualized under a laser scanning confocal Zeiss Axiovert BioRad Radience 2100 microscope.

\section{Statistical evaluations}

All data are presented as means \pm S.E.M. Comparisons between control and treatment were performed using Student's paired t-test. A value of at least $\mathrm{P}<0.05$ was considered to be statistically significant. 
A

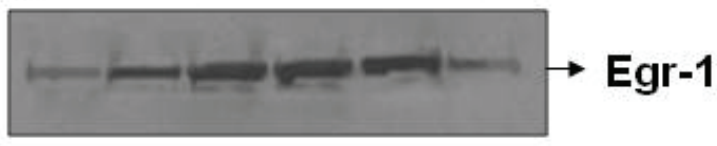

$\begin{array}{lllllll}0 & 1 & 2 & 4 & 6 & 12 & (\mathrm{~h}) \\ \mathrm{H}_{2} \mathrm{O}_{2}(200 \mu \mathrm{M}) & \end{array}$

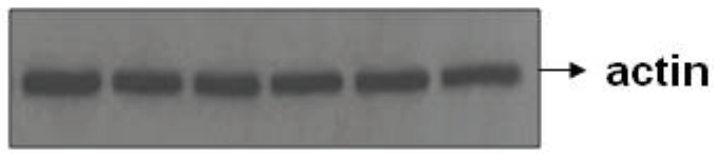

C

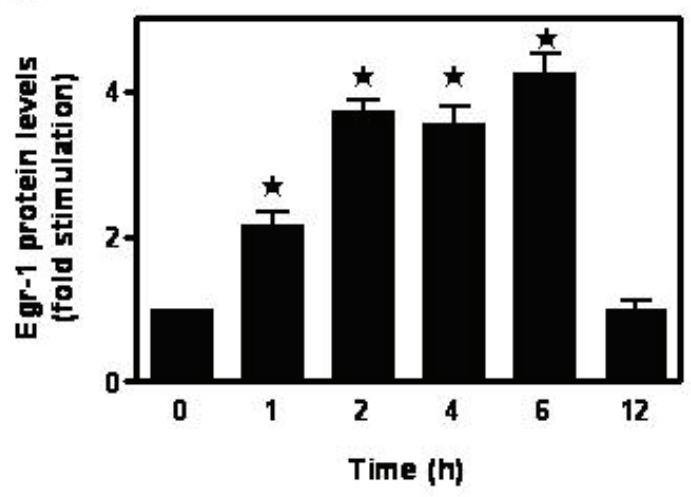

B
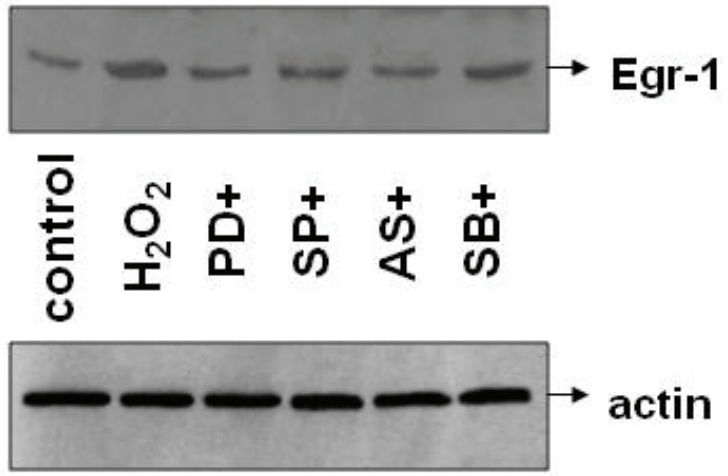

D

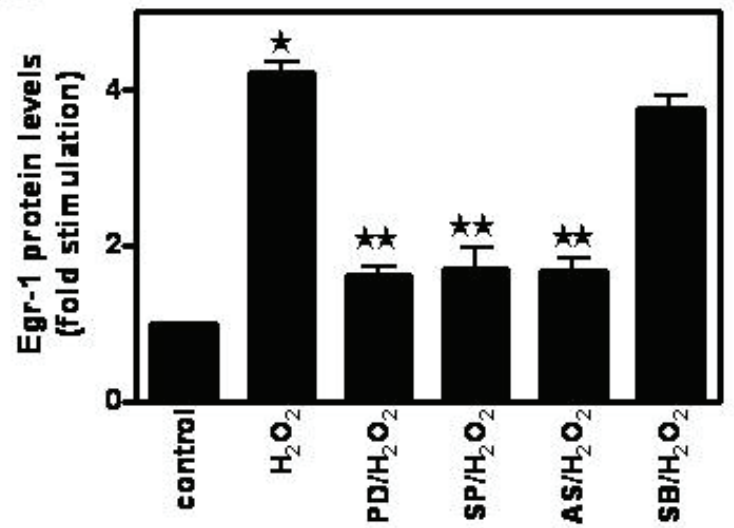

Fig. 2. (A) Kinetics of Egr-1 protein expression levels in $\mathrm{H}_{2} \mathrm{O}_{2}$-treated $\mathrm{H} 9 \mathrm{c} 2$ cardiomyoblasts. $\mathrm{H} 9 \mathrm{c} 2$ cells were left untreated (control) or were exposed to $200 \mu \mathrm{M} \mathrm{H}_{2} \mathrm{O}_{2}$ for the times indicated. (B) Effect of PD98059, SP600125, AS601245 and SB203580 on Egr-1 response. H9c2 cells were left untreated or were pre-incubated with $10 \mu \mathrm{M}$ PD98059 (PD), $10 \mu \mathrm{M}$ SP600125 (SP), $1 \mu \mathrm{M}$ AS601245 (AS) and $10 \mu \mathrm{M}$ SB203580 (SB) for $30 \mathrm{~min}$, then exposed to $200 \mu \mathrm{M} \mathrm{H} \mathrm{H}_{2}$ for $2 \mathrm{~h}$ in the absence or presence of the inhibitors. Nuclear cell extracts $(30 \mu \mathrm{g})$ were subjected to SDS-PAGE and immunoblotted with an antibody for total Egr-1 protein levels (A and $\mathbf{B}$ upper panels). To verify equal loading, the membranes were then stripped and re-incubated with a specific anti-actin antibody (A and $\mathbf{B}$ lower panels). Bands were quantified by laser scanning densitometry (C and D). Blots and results shown are representative of at least three independent experiments. Results are means \pm SEM for at least three independent experiments. $* p<0.001$ compared to control values; $* * \mathrm{p}<0.001$ compared to identically treated cells in the absence of inhibitors.

\section{Results}

$\mathrm{H}_{2} \mathrm{O}_{2}$ stimulates Egr-1 mRNA levels in $\mathrm{H} 9 \mathrm{c} 2$ cells in a JNK- and ERK-dependent manner

There is emerging evidence revealing Egr-1 diverse biological effects under stressful conditions. Given the importance of the triggered cellular responses by oxidative insults in the myocardium, Egr-1 transcriptional response to hydrogen peroxide treatment was examined in the present study by exposure of $\mathrm{H} 9 \mathrm{c} 2$ cells to $200 \mu \mathrm{M} \mathrm{H}_{2} \mathrm{O}_{2}$. Thus, Egr-1 mRNA was found to be induced from $1 \mathrm{~h}(3.04 \pm 0.52$ fold relative to control), maximized at $2 \mathrm{~h}(6.03 \pm 0.16$ fold relative to control $)$ (Fig. 1A, upper panel) decreasing thereafter. GAPDH (glyceraldehydes-3-phosphate dehydrogenase) mRNA levels were also assayed as a housekeeping gene (Figures 1A, C bottom panels). Data shown (Figs 1B and 1D) represents densitometric analysis of Egr-1 PCR product bands normalized for the respective GAPDH values. Subsequently, to probe into the actual pathways transducing this effect, we tried to determine the signaling cascades involved in stimulation of Egr-1 transcript levels by $\mathrm{H}_{2} \mathrm{O}_{2}$. To this end, various pharmacological inhibitors were used: PD98059 that blocks the ERK1/2 pathway, SP600125 and AS601245 (both selective JNKs inhibitors) and SB203580 (a p38MAPK inhibitor). The effect of cycloheximide which is known to suppress de novo protein synthesis as well as actinomycin D which is a widely used transcription inhibitor, were also examined. DMSO as well as the 
inhibitors alone had no effect on Egr-1 mRNA levels (data not shown). As shown in Figure 1C (upper panel) and Figure 1D, we observed that pretreatment of H9c2 cells with PD98059 and SP600125 as well as with AS601245 almost abrogated $\mathrm{H}_{2} \mathrm{O}_{2}$-stimulated Egr-1 response. These results also indicate that ERKs and JNKs participate in $\mathrm{H}_{2} \mathrm{O}_{2}$-induced Egr-1 mRNA upregulation in H9c2 cells. In contrast, there is no apparent intermediacy of p38-MAPK in the observed response. Furthermore, the latter was abolished in the presence of actinomycin D, indicating Egr-1 regulation at the transcriptional level. Additionally, $\mathrm{H}_{2} \mathrm{O}_{2}$-induced Egr-1 levels were markedly enhanced in the presence of cycloheximide, an effect that confirms Egr-1 to function as an immediate early response gene.

ERKs and JNKs are involved in Egr-1 protein upregulation by $\mathrm{H}_{2} \mathrm{O}_{2}$ in $\mathrm{H} 9 \mathrm{c} 2$ cells

Subsequently, an effort was made to examine the time-dependent profile of Egr-1 response to $\mathrm{H}_{2} \mathrm{O}_{2}$ at the protein level. As shown in Figures $2 \mathrm{~A}$ and $2 \mathrm{C}$, a sustained upregulation of Egr-1 protein levels was observed in samples from nuclear extracts at $1 \mathrm{~h}$ after the onset of stimulation $(2.17 \pm 0.17$ fold relative to control) with maximal values being attained at $2 \mathrm{~h}(3.71 \pm 0.15$ fold relative to control) and being sustained for at least $6 \mathrm{~h}$, declining thereafter. Additionally, using various inhibitors, the contribution of a number of signaling pathways to Egr-1 protein upregulation was assessed. DMSO as well as the inhibitors alone had no effect on Egr-1 protein levels (data not shown). Our results suggest that the latter are upregulated via a mechanism involving ERKs and JNKs, since the respective inhibitors almost ablated the observed response (Figs 2B and 2D). SB203580, a p38-MAPK inhibitor, had no effect. Equal protein loading was verified by reprobing the membranes with a specific anti-actin antibody (Figs $2 \mathrm{~A}$ and 2B, bottom panels).

\section{Distribution pattern of Egr-1 in $\mathrm{H}_{2} \mathrm{O}_{2}$-treated $\mathrm{H} 9 \mathrm{c} 2$ cells} Our aforementioned findings prompted us to look into Egr-1 distribution pattern as well as into the mechanism modulating the latter. To our knowledge, this is the first report describing regulation of Egr-1 subcellular localization in cardiac cells exposed to hydrogen peroxide. Effectively, monitoring the distribution profile of this transcription factor, we observed that in untreated cells (Fig. 3 - control) the basal minimal immunofluorescent signal detected was located in both the cytoplasm and nucleus. Interestingly, after exposure of $\mathrm{H} 9 \mathrm{c} 2$ cells for $2 \mathrm{~h}$ to $200 \mu \mathrm{M} \mathrm{H}_{2} \mathrm{O}_{2}$, there was a significant enhancement of Egr-1 staining which was accumulated exclusively in the nucleus (Fig. 3 - $\mathrm{H}_{2} \mathrm{O}_{2}$ ). In the presence of PD98059 as well as SP600125 (ERKs and JNKs selective inhibitors, respectively), there was a marked decrease in Egr-1 immunostaining almost reaching basal levels, which was once more distributed in the nucleus as well as in the cytoplasm (Fig. $3-\mathrm{PD} / \mathrm{H}_{2} \mathrm{O}_{2}$ and $\mathrm{SP} / \mathrm{H}_{2} \mathrm{O}_{2}$, respectively). A minimal immunofluorescent signal was detected when the inhibitors were used alone in both the cytoplasmic and nuclear compartments (data not shown). Thus, it appears that after treatment with $\mathrm{H}_{2} \mathrm{O}_{2}$, one observes the nuclear sequestration of enhanced Egr-1 protein levels, a process found to be both ERK- and JNK-dependent.

\section{Discussion}

Several cardiac pathological conditions have as their prime cause the exposure to increased levels of reactive oxygen species (ROS) which induce the apoptotic death of cardiac myocytes (Byrne et al. 2003, Feuerstein and Young 2000). Hydrogen peroxide constitutes one of the most widely investigated ROS that has been found to exert a dual effect by either stimulating proliferation or triggering apoptosis (Kanno et al. 2000, Sundaresan et al. 1995, Wei et al. 2000). Early growth response factor-1 (Egr-1) was originally characterized as an immediate early gene (IEG) that is induced by stimuli implicated in vascular pathology, i.e. growth factors, cytokines, hypoxia, hyperoxia, hemorrhagic shock injury (Gess et al. 1997, Silverman and Collins T 1999). Given the fact that accumulating reports account for a key role of Egr-1 and its targets in orchestrating cellular response following oxidative stress (Jin et al. 2000), it was of interest to probe into its regulation by $\mathrm{H}_{2} \mathrm{O}_{2}$ in $\mathrm{H} 9 \mathrm{c} 2$ cardiac cells.

Accordingly, in our hands, the exposure of $\mathrm{H} 9 \mathrm{c} 2$ cells to $200 \mu \mathrm{M} \mathrm{H} \mathrm{H}_{2} \mathrm{O}_{2}$ resulted in the transient upregulation of Egr-1 mRNA (Figs 1A and 1B). In aortic smooth muscle cells, Jin et al. (2000) have shown $\mathrm{H}_{2} \mathrm{O}_{2}$ induced Egr-1 mRNA to peak within $1 \mathrm{~h}$ and its regulation by a tyrosine kinase-dependent mechanism. In our study, induction of Egr-1 mRNA levels was mediated via ERKs and JNKs signaling cascades, as evidenced by abrogation of the observed effect in the presence of their respective pharmacological inhibitors: PD98059 and SP600125 or alternatively AS601245 (Figs 1C and 1D). 
On the contrary, SB203580 (a p38-MAPK inhibitor) did not block $\mathrm{H}_{2} \mathrm{O}_{2}$-induced Egr-1 mRNA stimulation. In line with our findings, numerous reports have shown ERKs to be involved in EGR-1 mRNA upregulation by diverse stimuli in a plethora of cell types and tissues. In particular, Hasan and Schafer (2008) have marked ERKdependent Egr-1 mRNA stimulation by hemin in vascular smooth muscle cells. In addition to this, Egr-1 transcription has also been shown to be regulated through an ERK-related mechanism, in astrocytes treated with endothelin-3 (Biesiada et al. 1996) as well as in primary neonatal cardiomyocytes treated with estrogen (deJager et al. 2001) and RAW macrophages exposed to hypoxia (Mishra et al. 2006). However, using NIH3T3 cells Lim et al. (1998) have shown that various forms of stress (UV radiation, heat shock) induce Egr-1 gene via a mechanism independent of ERKs, involving p38-MAPK and JNKs.
Egr-1

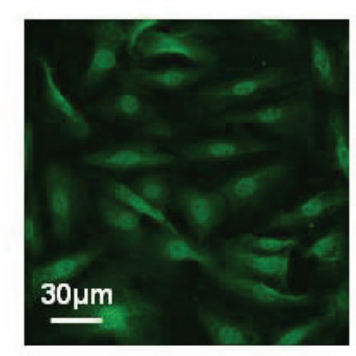

control control

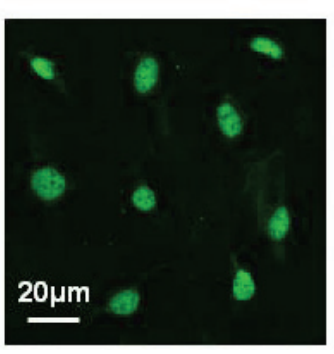

Egr-1

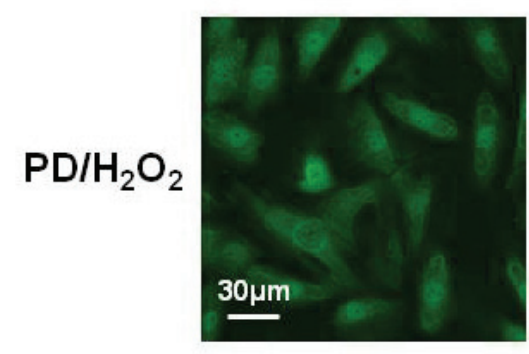

$\mathrm{SP} / \mathrm{H}_{2} \mathrm{O}_{2}$

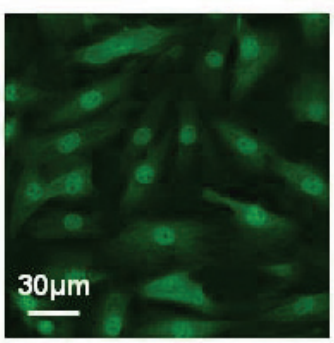

nucleus
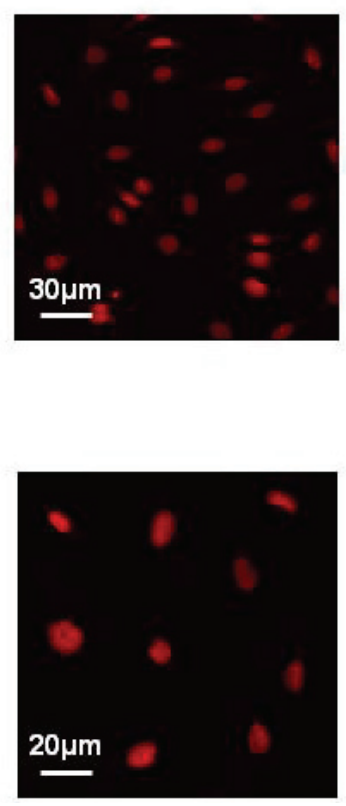

nucleus
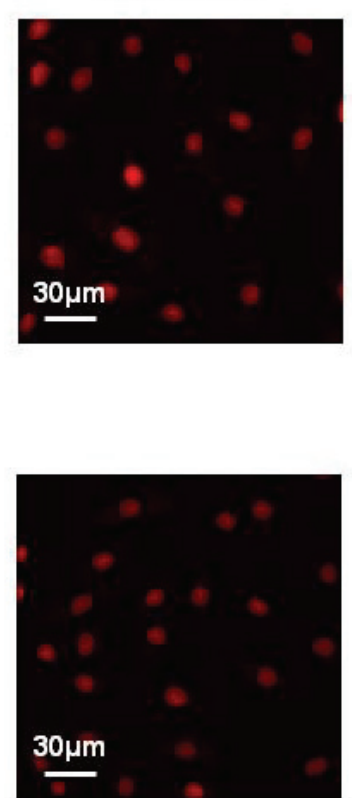

merge
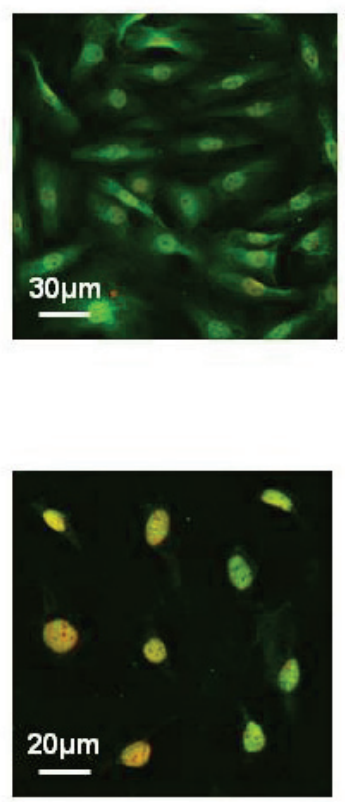

merge
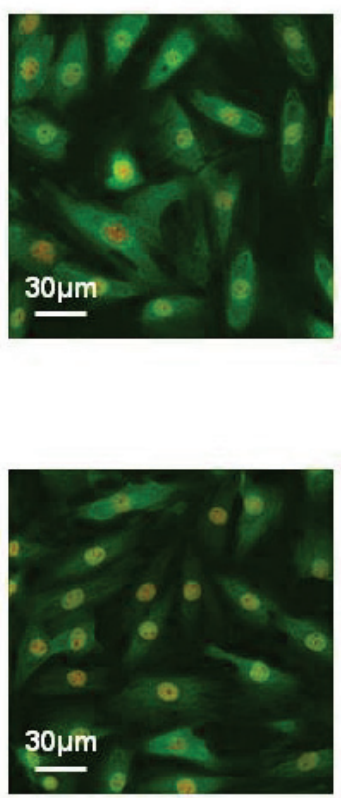

Fig. 3. Localization profile of Egr-1 protein levels in $\mathrm{H} 9 \mathrm{c} 2$ cardiomyoblasts left untreated (control) or exposed to $200 \mu \mathrm{M} \mathrm{H}_{2} \mathrm{O}_{2}$ for $2 \mathrm{~h}$. Cells were subjected to immunocytochemical analysis with an antibody directed against total Egr-1 protein levels (green fluorescence). To reveal nuclear morphology nuclei were stained with TO-PRO-3 iodide (642/661) (red fluorescence). Following mounting, chamber slides were visualized under a laser scanning confocal Zeiss Axiovert BioRad Radience 2100 microscope. Representative images are shown, indicative of at least three independent experiments. 

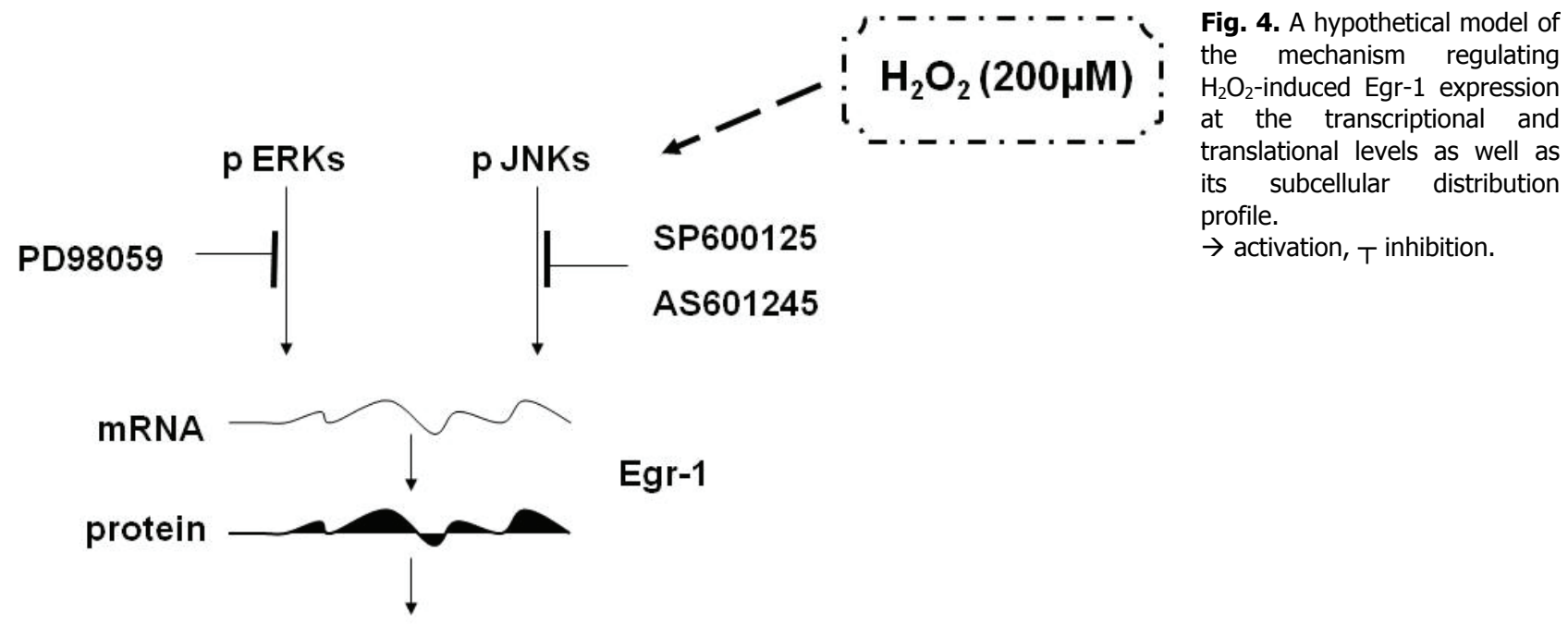

nuclear translocation \& sequestration

Interestingly, only a few investigators have observed the participation of JNKs in stimulation of Egr-1 mRNA levels. In particular, Chung et al. (2007) have reported amitriptyline (an antidepressant inhibiting neurotransmitter reuptake) to induce Egr-1 gene expression in rat $\mathrm{C} 6$ glial cells via ERKs and JNKs, using their respective selective inhibitors. Similarly, Choi et al. (2008) have demonstrated Egr-1 induction by curcumin in U-87MG human glioblastoma cells to involve ERKs and JNKs. Given the different mechanisms implicated in each setting, one can postulate that the involvement of MAPKs in the transcriptional regulation of Egr-1 is stimulus- and cell type-specific. The observed abrogation of $\mathrm{H}_{2} \mathrm{O}_{2}$-induced Egr-1 mRNA by actinomycin D, a known inhibitor of gene transcription (McConkey et al. 1989a, 1989b), confirmed that this response is regulated at the transcriptional level, while the additive effect of cycloheximide on induction of Egr-1 mRNA by $\mathrm{H}_{2} \mathrm{O}_{2}$, substantiated that the latter constitutes an immediateearly response, underscoring Egr-1 function as an IEG immediate early gene (Milbrandt 1987) (Figs 1C and 1D).

Subsequently, taking into account the fact that in skeletal muscle cells the induction of Egr-1 mRNA by various stimuli (including endothelin-1, angiotensin II and alpha-adrenergic agonists) was followed by a translational block (Maass et al. 1994), it appeared of interest to elucidate the mechanism modulating expression of $\mathrm{H}_{2} \mathrm{O}_{2}$-induced Egr-1 protein levels in our experimental model. In agreement with studies reporting Egr-1 coordinated upregulation of mRNA and protein levels, we found Egr-1 protein to be maximally induced at $2 \mathrm{~h}$ of $\mathrm{H}_{2} \mathrm{O}_{2}$ treatment, returning to basal levels after $6 \mathrm{~h}$ (Figs 2A and 2C). Similarly to our findings, Shamin et al. (1999) reported Egr-1 upregulation at both mRNA and protein levels in neonatal cardiomyocytes exposed to endothelin-1, angiotensin II or norepinephrine, with Hasan and Schafer (2008) reporting a similar effect in vascular smooth muscle cells exposed to hemin. What is more, related to our observation of Egr-1 protein upregulation by $\mathrm{H}_{2} \mathrm{O}_{2}$ in an ERK- and JNK-dependent manner, numerous reports have also pointed to the involvement of ERKs, i.e. in estrogen-treated neonatal cardiac myocytes (deJager et al. 2001) and prostaglandintreated cardiac myocytes (Xu et al. 2008). Additionally, in accordance with our findings, Ahn et al. (2007) have observed that Egr-1 protein upregulation in phorbol myristate-treated human glioma cells was ERK- and JNK-dependent. However, contrary to our results, Wang et al. (2005) have found p38-MAPK rather than ERKs or JNKs, to mediate isoproterenol-induced Egr-1 protein expression in $\mathrm{H} 9 \mathrm{c} 2$ cells.

In terms of Egr-1 subcellular localization, we have shown $\mathrm{H}_{2} \mathrm{O}_{2}$ to cause its nuclear sequestration (Fig. $3-\mathrm{H}_{2} \mathrm{O}_{2}$ vs. control). To our knowledge, our study is the first to report the involvement of both ERKs (Fig. 3 $-\mathrm{PD} / \mathrm{H}_{2} \mathrm{O}_{2}$ ) and JNKs (Fig. $3-\mathrm{SP} / \mathrm{H}_{2} \mathrm{O}_{2}$ ) in the enhanced expression and spatial distribution, i.e. nuclear accumulation of Egr-1 protein in cardiac myocytes exposed to $\mathrm{H}_{2} \mathrm{O}_{2}$, potentially mediating this transcription factor's interaction with its substrates, allowing thereafter for any modulation of gene expression. In accordance with our findings, Moon et al. (2007) have observed that in human intestinal epithelial cells exposed to sulindac sulfide, a non-steroidal anti-inflammatory drug, the promoted expression and nuclear translocation of Egr-1 was blocked in the presence of an ERK cascade inhibitor. 
Egr-1 has been found to play a significant role in preservation of cardiac function and pathogenesis of vascular diseases, because Okada et al. (2002) noted the fundamental contribution of Egr-1 induction to the development of cardiac allograft vasculopathy. Furthermore, the involvement of Egr-1 in regulation of sodium-calcium exchanger-1 (NCX1) as well as in fibroblast growth factor-2 (FGF-2) gene expression in cardiac myocytes, further substantiates Egr-1 cardioprotective properties (Jimenez et al. 2004, Wang et al. 2005). However, recent evidence also denotes the possible implication of Egr-1 in the pathogenesis of myocardial ischemia/reperfusion injury, with Egr-1 inhibition leading to amelioration of hemodynamics in vivo and to a relief of myocardial injuries in morphology and structure as evidenced by an increase of cell viability (Zhang et al. 2008). The controversy concerning Egr-1 physiological role is further enhanced by the report of Kasneci et al. (2009) who demonstrated Egr-1 to act as a transcriptional repressor of calsequestrin (CSQ) resulting in its downregulation, with negative effects on cardiac function. This is due to the fact that CSQ constitutes the major calcium storage protein that links excitation-contraction coupling in the cardiac sarcoendoplasmic reticulum (Chopra et al. 2007).

One can deduce from the above that elucidating the signal transduction pathways mediating Egr-1 response to hydrogen peroxide appears compelling, particularly in cardiac myocytes. Overall, our data disclose the role of ERKs and JNKs in the regulation of Egr-1 temporal and spatial expression pattern in $\mathrm{H}_{2} \mathrm{O}_{2}$ treated cardiac cells. Figure 4 shows a schematic representation of our results. Nevertheless, further studies are required to elucidate the precise effects of this immediate responsive transcription factor in the complex context of the myocardium, justifying Egr-1 characterization as a primary regulator of cell fate under stressful conditions.

\section{Conflict of Interest}

There is no conflict of interest.

\section{Acknowledgements}

This work was funded by Special Research Account of the University of Athens grants.

\begin{abstract}
Abbreviations
Early growth response factor-1 (Egr-1); Extracellular signal-regulated kinases (ERKs); cJun-N-terminal kinases (JNKs); Mitogen-activated protein kinases (MAPKs); glyceraldehyde-3-phosphate dehydrogenase (GAPDH); Dimethyl-sulfoxide (DMSO); Sodium dodecyl sulphatepolyacrylamide gel electrophoresis (SDS-PAGE); polymerase chain reaction (PCR)
\end{abstract}

\section{References}

AGGELI IK, GAITANAKI C, BEIS I: Involvement of JNKs and p38-MAPK/MSK1 pathways in H2O2-induced upregulation of heme oxygenase-1 mRNA in H9c2 cells. Cell Signal 18: 1801-1812, 2006.

AHN BH, PARK MH, LEE YH, MIN DO S: Phorbol myristate acetate-induced Egr-1 expression is suppressed by phospholipase D isozymes in human glioma cells. FEBS Lett 581: 5940-5944, 2007.

BALLA G, JACOB HS, EATON JW, BELCHER JD, VERCELLOTTI GM: Hemin: a possible physiological mediator of low density lipoprotein oxidation and endothelial cell injury. Arterioscler Thromb 11: 1700-1711, 1991.

BIESIADA E, RAZANDI M, LEVIN ER: Egr-1 activates basic fibroblast growth factor transcroption. J Biol Chem 271: 18576-18581, 1996.

BOGOYEVITCH MA: Signalling via stress-activated mitogen-activated protein kinases in the cardiovascular system Cardiovasc Res 45: 826-842, 2000.

BRUNEAU BG, PIAZZA LA, DE BOLD AJ: Alpha (1)-adrenergic stimulation of isolated rat atria results in discoordinate increases in natriuretic peptide secretion and gene expression and enhances Egr-1 and c-myc expression. Endocrinology 137: 137-143, 1996.

BYRNE JA, GRIEVE DJ, CAVE AC, SHAH AM: Oxidative stress and heart failure. Arch Mal Coeur Vaiss 96: $214-$ $221,2003$.

CAO X, MAHENDRAN R, GUY GR, TAN YH: Detection and characterization of cellular EGR-1 binding to its recognition site. J Biol Chem 268: 16949-16957, 1993. 
CHIU JJ, WUNG BS, HSIEH HJ, LO LW, WANG DL: Nitric oxide regulates shear stress-induced early growth response-1. Expression via the extracellular signal-regulated kinase pathway in endothelial cells. Circ Res $\mathbf{8 5}$ : 238-246, 1999.

CHOI BH, KIM CG, BAE YS, LIM Y, LEE YH, SHIN SY: p21 Waf1/Cip1 expression by curcumin in U-87MG human glioma cells: role of early growth response-1 expression. Cancer Res 68: 1369-1377, 2008.

CHOPRA N, KANNANKERIL PJ, YANG T, HLAING T, HOLINSTAT I, ETTENSOHN K, PFEOFER K, AKIN B, JONES LR, FRANZINI-ARMSTRONG C, KNOLLMANN BC: Modest reduction of cardiac calsequestrin increase sarcoplasmic reticulum $\mathrm{Ca}^{2+}$ leak independent of luminal $\mathrm{Ca}^{2+}$ and trigger ventricular arrthymias in mice. Circ Res 101: 617-626, 2007.

CHUNG EY, SHIN SY, LEE YH: Amitriptyline induces early growth response-1 gene expression via ERK and JNK mitogen-activated protein kinase pathways in rat C6 glial cells. Neurosci Lett 422: 43-48, 2007.

DATTA R, RUBIN E, SUKHATME V, QURESHI S, HALLAHAN D, WEICHSELBAUM RR, KUFE DW: Ionizing radiation activates transcription of the EGR1 gene via CArG elements. Proc Natl Acad Sci USA 89: 1014910153, 1992.

DE JAGER T, PELZER T, MULLER-BOTZ S, IMAM A, MUCK J, NEYSES L: Mechanisms of estrogen receptor action in the myocardium. J Biol Chem 276: 27873-27880, 2001.

DEPRE C, TOMLINSON JE, KUDEJ RK, GAUSSIN V, THOMPSON E, KIM SJ, VATNER DE, TOPPER JN, VATNER SF: Gene program for cardiac cell survival induced by transient ishemia in conscious pigs. Proc Natl Acad Sci USA 98: 9336-9341, 2001.

EID MA, KUMAR MV, ICZKOWSKI KA, BOSTWICK DG, TINDALL DJ: Expression of early growth response genes in human prostate cancer. Cancer Res 58: 2461-2468, 1998.

FAHMY RG, KHACHIGIAN LM: Antisense Egr-1 RNA driven by the CMV promoter is an inhibitor of vascular smooth muscle cell proliferation and regrowth after injury. J Cell Biochem 84: 575-582, 2002.

FERRARI R, GUARDIGLI G, MELE D, PERCOCO GF, CECONI C, CURELLO S: Oxidative stress during myocardial ischaemia and heart faiklure. Curr Pharm Des 10: 1699-1711, 2004.

FEUERSTEIN GZ, YOUNG PR: Apoptosis in cardiac disease states: stress- and mitogen-activated signaling pathways. Cardiovasc Res 45: 560-569, 2000.

FLOTATS A, CARRIO I: Non-invasive in vivo imaging of myocardial apoptosis and necrosis. Eur J Nucl Med Mol Imaging 30: 615-630, 2003.

GESS B, WOLF K, KURTZ A: Lack of control by immediate early response genes for the oxygn regulation of erythropietin gene expression. Pflugers Arch 433: 827-831, 1997.

GOEDERT M, CUENDA A, CRAXTON M, JAKES R, COHEN P: Activation of the novel stress-activated protein kinase SAPK4 by cytokines and cellular stresses is mediated by SKK3 (MKK6); comparison of its substrate specificity with that of other SAP kinases. EMBO J 16: 3563-3571, 1997.

HAN H, LONG H, WANG H, WANG J, ZHANG Y, WANG Z: Progressive apoptotic cell death triggered by transient oxidative insult in $\mathrm{H} 9 \mathrm{c} 2$ rat ventricular cells: a novel pattern of apoptosis and the mechanisms. Am J Physiol 286: H2169-H2182, 2004.

HASAN RN, SCHAFER AI: Hemin upregulates Egr-1 expression in vascular smooth muscle cells via ROS-ERK1/2Elk-1 and NfkB. Circ Res 102: 42-50, 2008.

HODGE C, LIAO J, STOFEGA M, GUAN K, CARTER-SU C, SCHWARTZ J: Growth hormone stimulates phosphorylation and activation of elk-1 and expression of c-fos, egr-1, and junB through activation of extracellular signal-regulated kinases 1 and 2. J Biol Chem 273: 31327-31336, 1998.

HUANG RP, FAN Y, DE BELLE I, NIEMEYER C, GOTTARDIS MM, MERCOLA D, ADAMSON ED: Decreased Egr-1 expression in human, mouse and rat mammary cells and tissues correlated with tumor formation. Int $J$ Cancer 72: 102-109, 1997.

JIMENEZ SK, SHEIKH F, JIN Y, DETILLIEUX KA, DHALIWAL J, KARDAMI E, CATTINI PA: Transcriptional regulation of FGF-2 gene expression in cardiac myocytes. Cardiovasc Res 62: 548-557, 2004.

JIN N, HATTON ND, HARRINGTON MA, XIA X, LARSEN SH, RHOADES RA: $\mathrm{H}_{2} \mathrm{O}_{2}$-induced Egr-1, Fra-1 and cjun gene expression is mediated by tyrosine kinase in aortic smooth muscle cells. Free Rad Biol Med 29: 736$746,2000$. 
KANNO S, ISHIWAKA M, TAKAYANAGI M, TAKAYANAGI Y, SASAKI K: Characterization of hydrogen peroxide-induced apoptosis in mouse primary cultured hepatocytes. Biol Pharm Bull 23: 37-42, 2000.

KASNECI A, KEMENY-SUSS NM, KOMAROVA SV, CHALIFOUR LE: Egr-1 negatively regulates calsequestrin expression and calcium dynamics in ventricular cells. Cardiovasc Res 81: 695-702, 2009.

KEMP TJ, CAUSTON H, CLERK A: Changes in gene expression induced by $\mathrm{H}(2) \mathrm{O}(2)$ in cardiac myocytes. Biochem Biophys Res Commun 307: 416-421, 2003.

KHACHIGIAN LM, LINDNER V, WILLIAMS AJ, COLLINS T: Egr-1-induced endothelial gene expression: a common theme in vascular injury. Science 271: 1427-1431, 1996.

KIMES BW, BRANDT BL: Properties of a clonal muscle cell line from rat heart. Exp Cell Res 98: 367-381, 1976.

KYRIAKIS JM, AVRUCH J: Sounding the alarm: protein kinase cascades activated by stress and inflammation. $J$ Biol Chem 271: 24313-24316, 1996.

LANOIX J, MULLICK A, HE Y, BRAVO R, SKUP D: Wild-type egr-1/Krox24 promotes and dominant-negative mutants inhibit, pluripotent differentiation of p19 embryonal carcinoma cells. Oncogene 17: 2495-2504, 1998.

LEMAIRE P, REVELANT O, BRAVO R, CHARNAY P: Two mouse genes encoding potential transcription factors with identical DNA-binding domains are activated by growth factors in cultured cells. Proc Natl Acad Sci USA 85: 4691-4695, 1988.

LEVIN WJ, PRESS MF, GAYNOR RB, SUKHATME VP, BOONE TC, REISSMANN PT, FIGLIN RA, HOLMES EC, SOUZA LM, SLAMON DJ: Expression patterns of immediate early transcription factors in human non-small cell lung cancer. Oncogene 11: 1261-1269, 1995.

LIM CP, JAIN N, CAO X: Stress-induced immediate-early gene, egr-1, involves activation of p38/JNK1. Oncogene 16: 2915-2926, 1998.

LIM RW, VARNUM BC, HERSCHMAN HR: Cloning of tetradecanoyl phorbol ester-induced 'primary response' sequences and their expression in density-arrested Swiss 3T3 cells and a TPA non-proliferative variant. Oncogene 1: 263-270, 1987.

MAASS A, GROHE C, SUKHATME VP, VETTER H, NEYSES L: Mitogenic signals control translation of the early growth response gene-1 in myogenic cells. Biochem Biophys Res Commun 202: 1337-1345, 1994.

MCCAFFREY TA, FU C, DU B, EKSINAR S, KENT KC, BUSH H Jr, KREIGER K, ROSENGART T, CYBULSKY MI, SILVERMAN ES, COLLINS T: High-level expression of Egr-1 and Egr-1-inducible genes in mouse and human atherosclerosis. $J$ Clin Invest 105: 653-662, 2000.

MCCONKEY DJ, HARTZELL P, AMADOR-PEREZ JF, ORRENIUS S, JONDAL M: Calcium-dependent killing of immature thymocytes by stimulation via the CD3/T receptor complex. J Immunol 143: 1801-1806, 1989.

MCCONKEY DJ, NICOTERA P, HARTZELL P, BELLOMO G, WYLLIE AH, ORRENIUS S: Glucocorticoids activate a suicidal process in thymocytes through an elevation of cytosolic $\mathrm{Ca}^{2+}$ concentration. Arch Biochem Biophys 269: 365-370, 1989.

MILBRANDT J: A nerve growth factor-induced gene encodes a possible transcriptional regulatory factor. Science $\mathbf{2 3 8}$ : 797-799, 1987.

MISHRA S, FUJITA T, LAMA VN, NAM D, LIAO H, OKADA M, MINAMOTO K, YOSHIKAWA Y, HARADA H, PINSKY D: Carbon monoxide rescues ischemic lungs by interrupting MAPK-driven expression of early growth response 1 gene and its downstream target genes. Proc Natl Acad Sci USA 103: 5191-5196, 2006.

MOON Y, YANG H, KIM YB: Up-regulation of Egr-1 via ERK1/2 signals attenuates sulindac sulfide-mediated cytotoxicity in the human intestinal epithelial cells. Toxicol Appl Pharmacol 223: 155-163, 2007.

OKADA M, WANG CY, HWANG DW, SAKAGUCHI T, OLSON KE, YOSHIKAWA Y, MINAMOTO K, MAZER SP, YAN SF, PINSKY DJ: Transcriptional control of cardiac allograft vasculopathy by early growth response gene-1 (Egr-1). Circ Res 91: 135-142, 2002.

ROSS R: The smooth muscle cell II. Growth of smooth musclen in culture and formation of elastic fibers. J Cell Biol 50: 172-186, 1998.

SAADANE N, ALPERT L, CHALIFOUR LE: Expression of immediate early genes, GATA-4, and Nkx2.5 in adrenergic-induced cardiac hypertrophy and during regression in adult mice. Br J Pharmacol 127: 1165-1176, 1999. 
SANTIAGO FS, LOWE HC, KAVURMA MM, CHESTERMAN CN, BAKER A, ATKINS DG, KHACHIGIAN LM: New DNA enzyme targeting Egr-1 mRNA inhibits vascular smooth muscle proliferation and regrowth after injury. Nat Med 5: 1264-1269, 1999.

SHAMIN A, PELZER T, GROHE C, NEYSES L: Induction of Egr-1 mRNA and protein by endothelin 1, angiotensin II and norepinephrine in neonatal cardiac myocytes. Mol Cell Biochem 195: 11-17, 1999.

SILVERMAN ES, COLLINS T: Pathways of Egr-1-mediated gene transcription in vascular biology. Am J Pathol 154: 665-670, 1999.

SU C, CHONG K, EDELSTEIN K, LILLE S, KHARDPRI R, LAI CC: Constitutive hsp70 attenuates hydrogen peroxide-induced membrane lipid peroxidation. Biochem Biophys Res Commun 265: 279-284, 1999.

SUKHATME VP, CAO XM, CHANG LC, TSAI-MORRIS CH, STAMENKOVITCH D, FERREIRA PC, COHEN DR, EDWARDS SA, SHOWS TB, CURRAN T: A zinc finger-encoding gene coregulated with c-fos during growth and differentiation, and after cellular depolarization. Cell 53: 37-43, 1988.

SUNDARESAN M, YU Z, FERRANS VJ, IRANI K, FINKEL T: Requirement for generation of $\mathrm{H}_{2} \mathrm{O}_{2}$ for plateletderived growth factor signal transduction. Science 270: 296-299, 1995.

TANAKA H, SAKURAI K, TAKAHASHI K, FUJIMOTO Y: Requirement of intracellular free thiols for hydrogen peroxide-induced hypertrophy in cardiomyocytes. J Cell Biochem 89: 944-955, 2003.

TURNER N, XIA F, AZHAR G, ZHANG X, LIU L, WEI JY: Oxidative stress induces DNA fragmentation and caspase activation via the c-Jun NH2-terminal kinase pathway in H9c2 cardiac muscle cells. $\mathrm{J}$ Mol Cell Cardiol 30: 1789-1801, 1998.

WANG C, DOSTANIC S, SERVANT N, CHALIFOUR LE: Egr-1 negatively regulates expression of the sodiumcalcium exchanger-1 in cardiomyocytes in vitro and in vivo. Card Res 65: 187-194, 2005.

WEI T, NI Y, HOU J, CHEN C, ZHAO B, XIN W: Hydrogen peroxide-induced oxidative damage and apoptosis in cerebellar granule cells: protection by Gingo biloba extract. Pharmacol Res 41: 427-433, 2000.

XU W, CHOU CL, SUN H, FUJINO H, CHEN QM, REGAN JW: FP prostanoid receptor mediated induction of the expression of early growth response factor-1 by activation of a Ras/Raf/MAPK signaling cascade. Mol Pharmacol 73: 111-118, 2008.

YAN SF, FUJTTA T, LU J, OKADA K, SHAN S, ZOU Y, MACKMAN N, PINSKY DJ, STERN DM: Egr-1 a master switch coordinating upregulation of divergent gene families underlying ischemic stress. Nat Med 6: 1355-1361, 2000.

ZHANG Y, SHI G, ZHENG L, LV Y, GAO P, HUANG Z, GAO F, ZHOU Y: The protective effect of Egr-1 antisense oligodeoxyribonucleotide on myocardial injury induced by ischemia-reperfusion and hypoxia reoxygenation. Cell Physiol Biochem 22: 645-652, 2008. 